\title{
UNCONVENTIONAL MONETARY POLICY OF THE EUROPEAN CENTRAL BANK ${ }^{*}$
}

\author{
Dario Hlupić Radić, LLM, Legal Advisor \\ Croatian National Bank \\ Trg hrvatskih velikana 3, 10000 Zagreb, Croatia \\ e-mail: dario.hlupic@hnb.hr
}

\begin{abstract}
Central banks control and manage the amount of money in the economy by steering short-term interest rates. Conventional short-term interest rate monetary policy has its limitations and the limit is zero lower bound. Zero lower bound means that the short-term interest rate cannot be set below 0\%. Managing the level of short-term interest rate a central bank can influence the overall availability and cost of credits and control the quantity of money in economy. If the level of the inflation rates are low and economic growth is weak a central bank can lower short-term interest rate to increase money supply in the economy.
\end{abstract}

After the 2008 financial crisis, the European Central Bank reduced short-term interest rates to zero or near zero to stimulate spending and investing with the expectations that this measure would be enough to induce economic growth in the euro area. Contrary to expectations, lowering short-term interest rates had little effects on economy in the euro area. Economic growth stagnated, inflation rates were very low with a tendency to deflation and the rate of the employment was low. Similar effects occurred in other countries where central banks also lowered short-term interest rates to zero or near zero.

Since then, the European Central Bank and other central banks did not achieve expected results using conventional short-term interest rates monetary policy so they had to use some other unconventional and non-standard monetary policy measures.

The European Central Bank conducted Asset purchases programme (APP) and Longer-term refinancing operations (LTRO) as non-standard monetary policy measures and unconventional balance sheet monetary policy. In this paper, these non-standard measures of the European Central Bank monetary policy will be explained. Characteristics of each measure will be provided and the measures will be compered. The European Central Bank has adopted a decision for each of the measures and those decisions as a legal basis for each of the measure will be given and explained. The European Central Bank expected some results and those expected results will be compared with achieved results of these non-standard measures. Alternative measures and other policies that can improve effectiveness of the unconventional monetary policy measures will be suggested and explained.

Keywords: money, central bank, monetary policy instruments, unconventional monetary policy measures, European Central Bank, interest rates, inflation, economic growth

Views expressed herein are personal to the author and not necessarily attributable to the Croatian National Bank 


\section{INTRODUCTION}

Monetary policy is the policy by which a central bank control and manage the amount of money in an economy. ${ }^{1}$ Adequate amount of money in the economy is essential because too much money in the economy can cause inflation, and vice versa very little money can cause deflation.

Central banks have the authority to issue money and to control the quantity of money in the economy. Central bank of the European Union is the European Central Bank and it has the right to authorise the issue of euro banknotes. According to the Treaty on the Functioning of the European Union, only such banknotes have the status of legal tender within the euro area. ${ }^{2}$ Furthermore, the European Central Bank has the authority to increase or decrease the quantity of money in the euro area economy by applying measures and instruments of monetary policy. One of the basic tasks of the European Central Bank is to define and implement the monetary policy of the European Union. ${ }^{3}$

A change in the quantity of money in the economy could be reflected in a change in the general level of prices. Prolonged periods of high inflation are typically associated with high monetary growth. The close association between the growth of money and inflation in the economy and the long-run neutrality of monetary policy have been confirmed by a very large number of economic studies. ${ }^{4}$ That means that the general level of prices and the inflation can be controlled by the central bank using the instruments of monetary policy.

Considering the stated, maintaining the price stability is the primary objective of the European Central Bank as it is specified in the Article 127 of the Treaty on the Functioning of the European Union. The European Central Bank shall also support the general economic policies in the European Union. ${ }^{5}$ Therefore, the price stability is the main objective but the European Central Bank will support the general economic policies, which include full employment and balanced economic growth.

Although the Treaty on the Functioning of the European Union has specified price stability as a primary objective of the European Central Bank, the Treaty did not define what the price stability actually means. Therefore, the European

Debarati, R., Power of money, Vij Books India Pvt. Ltd. New Delhi, 2011, p. 11

Article 128(1) of the Treaty on the Functioning of the European Union, OJ C 326, 26.10.2012, p. 1-12 (TFEU)

3 Article 127(2) TFEU

4 Executive Board of the ECB (2011): The Monetary Policy of the ECB 2011, ECB, Frankfurt, p. 55-56

5 Article 127(1) TFEU 
Central Bank's Governing Council adopted a quantitative definition of price stability in October 1998 and clarified it in 2003. By that definition, price stability means maintaining inflation rates below, but close to $2 \%$ over the medium term. ${ }^{6}$ According to that definition of price stability the European Central Bank is committed to avoiding both inflation that is persistently too high and inflation that is persistently too low which includes deflation.

Monetary policy of the European Central Bank operates by managing the level of short-term interest rates and influencing the overall availability and cost of credits in the euro area economy. The European Central Bank may conduct open market operations to steer interest rates, manage the liquidity situation in the financial market and signal the stance of monetary policy. ${ }^{7}$ Therefore, the monetary policy directly affects short-term interest rates and indirectly affects longer-term interest rates, currency exchange rates, and prices of equities and other assets and thus wealth. Through these channels, monetary policy influences household spending, business investment, production, employment and inflation.

The European Central Bank has the authority to increase or to reduce short-term interest rates on loans that it provides to banks and with that authority, it can increase or decrease the liquidity of the banking system and the quantity of money in the economy. Higher short-term interest rates reduce the demand for loans and they make loans less attractive for households and companies, which reduces quantity of money in the economy. At the same time, saving becomes more attractive since the return on the savings is increased. Decrease in spending and investing decreases inflation and may initiate deflation. Lowering short-term interest rates does the opposite. Lower short-term interest rates increase liquidity of the banking system, they increase the demand for loans, consequently increasing spending and investing. Lower short-term interest rate increases quantity of money in the economy but it puts pressure on prices and inflation.

Conventional short-term interest rate monetary policy has its limitations. Central banks can lower short-term interest rate down to $0 \%$ but it cannot be lower than $0 \%$. It is called zero lower bound problem. Global financial crisis that fully erupted during 2008 has shown disadvantages of standard short-term interest rate monetary policy. During the crisis, all major central banks including the European Central Bank reduced short-term interest rates near to zero or to zero to affect spending and investing which should have stimulated economic growth and rise

European Central Bank (2006): Price stability - Objective of the Eurosystem, ECB, MP.001 08/06, p. 2 Article 5 of the Guideline (EU) 2015/510 of the European Central Bank of 19 December 2014 on the implementation of the Eurosystem monetary policy framework (ECB/2014/60) OJ L 91, 2.4.2015, p. $3-135$ 
inflation levels. Contrary to expectations, lowering short-term interest rates had little effects on economies. Economic growth stagnated, inflation rates were very low with a tendency to deflation and central banks had to use some other nonstandard and unconventional measures to achieve price stability and to support economic growth.

\section{INSTRUMENTS AND LEGAL GROUNDS OF THE UNCONVENTIONAL MONETARY POLICY ISSUED BY THE EUROPEAN CENTRAL BANK}

This section provides an overview of a non-standard and unconventional monetary policy measures issued by the European Central Bank, its characteristics and legal grounds of these measures.

Since 2009, the European Central Bank implemented non-standard monetary policy measures in two ways: one is Asset purchases programme (APP) and the second is Longer-term refinancing operations (LTRO).

Asset purchases programme as a non-standard set of monetary policy measures started on 2 July 2009 with the first covered bond purchase programme (CBPP1). The European Central Bank issued Decision on the implementation of the covered bond purchase programme $(\mathrm{ECB} / 2009 / 16)$. Decision stated that objectives of that covered bond purchase programme were: "(a) promoting the ongoing decline in money market term rates; (b) easing funding conditions for credit institutions and enterprises; (c) encouraging credit institutions to maintain and expand their lending to clients; and (d) improving market liquidity in important segments of the private debt securities market." 8

The programme was targeted at nominal amount of $€ 60$ billion of eligible covered bonds. Covered bonds eligible for purchase under the programme were covered bonds that: could be used as collateral for Eurosystem credit operations, complied with the criteria for collective investment in transferable securities, had an issue volume of more than $€ 100$ million and were given a minimum rating of AA or equivalent by at least one of the major rating agencies (Fitch, Moody's, S\&P or $\mathrm{DBRS}$ ), in any case, not lower than BBB-/Baa3, and had underlying assets that include exposure to private and/or public entities. ${ }^{9}$

8 Recital 2 of 2009/522/EC: Decision of the European Central Bank of 2 July 2009 on the implementation of the covered bond purchase programme (ECB/2009/16), OJ L 175, 4.7.2009, p. 18-19 (CBPP1 Decision)

9 Article 2 of the CBPP1 Decision 
The programme ended, as planned, on 30 June 2010 when it reached a nominal amount of $€ 60$ billion. The European Central Bank intended to hold the assets bought under this programme until maturity. ${ }^{10}$

The second Asset purchases programme started on 14 May 2010 with the securities markets programme (SMP). The European Central Bank issued Decision establishing a securities markets programme (ECB/2010/5). Under that programme, the European Central Bank decided to purchase on the secondary market eligible marketable debt instruments issued by the central governments or public entities of the euro area Member States and on the primary and secondary markets eligible marketable debt instruments issued by private entities incorporated in the euro area. Marketable debt instruments will be eligible for outright purchase under the programme if they fulfil general criteria in order to be eligible for Eurosystem monetary policy operations. ${ }^{11}$

The Governing Council of the European Central Bank explained that, in view of the current exceptional circumstances in financial markets, characterised by severe tensions in certain market segments that were hampering the monetary policy transmission mechanism, and thereby the effective conduct of monetary policy oriented towards price stability in the medium term, a temporary securities markets programme was initiated. Governing Council terminated the SMP programme by decision on 6 September 2012. The existing securities in the SMP portfolio was held to maturity.

The third Asset purchases programme started on 3 November 2011 with the second covered bond purchase programme (CBPP2). The European Central Bank issued Decision of on the implementation of the second covered bond purchase programme (ECB/2011/17). The objectives of the second programme were also to contribute to: "(a) easing funding conditions for credit institutions and enterprises and (b) encouraging credit institutions to maintain and expand lending to their clients." 12

The programme was targeted at nominal amount of $€ 40$ billion of eligible covered bonds and ended on 31 October 2012. ${ }^{13}$

10 ECB Press release (2010): Covered bond purchase programme completed, ECB Frankfurt, 30 June 2010 [https://www.ecb.europa.eu/press/pr/date/2010/html/pr100630.en.html] Accessed 15.04.2019

11 Articles 1 and 2 of 2010/281 Decision of the European Central Bank of 14 May 2010 establishing a securities markets programme (ECB/2010/5) (OJ L 124, 20.5.2010), p. 8-9 (SMP Decision)

12 Recital 3 of 2011/744/: Decision of the European Central Bank of 3 November 2011 on the implementation of the second covered bond purchase programme (ECB/2011/17) OJ L 297, 16.11.2011, p. 70-71 (CBPP2 Decision)

13 Articles 1-4 of CBPP2 Decision 
On 8 December 2011 the Governing Council of the European Central Bank decided on additional enhanced credit support measures to support bank lending and liquidity in the euro area money market. The Governing Council has decided to conduct two longer-term refinancing operations (LTRO) with a maturity of 36 months and with the option of early repayment after one year. ${ }^{14}$

These aforementioned programmes were temporary and they were limited in volume of securities that were purchased. Since the effects of these Asset purchases programmes and long-term refinancing operations were weak, the European Central Bank continued with the non-standard monetary policy measures.

On 29 July 2014, the European Central bank issued a Decision on measures relating to targeted longer-term refinancing operations (ECB/2014/34) (TLTRO I) in pursuing its price stability mandate and to enhance the functioning of the monetary policy transmission mechanism by supporting lending to real economy over a period of two years. ${ }^{15}$ TLTRO I provided financing to credit institutions for periods of up to four years. They offered long-term funding to banks at almost the same conditions as in main refinancing operations in order to further ease private sector credit conditions and stimulate bank lending to the real economy. TLTRO I aimed to support bank lending to the non-financial private sector, meaning households and non-financial corporations, in Member States whose currency is the euro.

The fourth Asset purchases programme started on 15 October 2014 with the third covered bond purchase programme (CBPP3). The European Central Bank issued Decision on the implementation of the third covered bond purchase programme $(\mathrm{ECB} / 2014 / 40)$. The objectives of the third covered bond purchase programme was: "Further enhance the transmission of monetary policy, facilitate credit provision to the euro area economy, generate positive spill-overs to other markets and, as a result, ease the ECB's monetary policy stance, and contribute to a return of inflation rates to levels closer to $2 \%$." 16 The programme continues but as of January 2019, the European Central Bank no longer conducts net purchases, and only

$14 \quad$ ECB Press release (2011): ECB announces measures to support bank lending and money market activity, ECB Frankfurt, 8 December 2011; [https://www.ecb.europa.eu/press/pr/date/2011/html/ pr111208_1.en.html] Accessed 15.04.2019

15 Recital 2 of 2014/541/EU: Decision of the European Central Bank of 29 July 2014 on measures relating to targeted longer-term refinancing operations (ECB/2014/34), OJ L 258, 29.8.2014, p. 11-29 (TLTRO I Decision)

16 Recital 2 of 2014/828/EU: Decision of the European Central Bank of 15 October 2014 on the implementation of the third covered bond purchase programme (ECB/2014/40), OJ L 335, 22.11.2014, p. 22-24 (CBPP3 Decision) 
continues to reinvest the principal payments from maturing securities held in the CBPP3 portfolio.

The fifth Asset purchases programme started on 19 November 2014 with the asset-backed securities purchase programme (ABSPP). The European Central Bank issued Decision on the implementation of the asset-backed securities purchase programme $(\mathrm{ECB} / 2014 / 45)$. The objectives of a new asset-backed securities purchase programme was the same as it had been for the third covered bond purchase programme and it targeted longer-term refinancing operations that were to further enhance the transmission of monetary policy, facilitate credit provision to the euro area economy, generate positive spill-overs to other markets and contribute to a return of inflation rates to levels closer to $2 \%$. Asset-backed securities eligible for the programme were securities that fulfil the eligibility criteria applicable to asset-backed securities submitted as collateral for Eurosystem monetary policy operations. ${ }^{17}$

As of January 2019, the European Central Bank no longer conducts net purchases under the asset purchase programmes, but continues to reinvest the principal payments from maturing securities purchased under the asset purchase programme (APP). The period of APP net asset purchases ended in December 2018. ${ }^{18}$

The sixth Asset purchases programme started on 4 March 2015 with the public sector asset purchase programme (PSPP). The European Central Bank issued Decision on a secondary markets public sector asset purchase programme (ECB/2015/10). Under the programme, the European Central Bank purchased public sector debt securities on the secondary markets. In terms of the size of the PSPP, the ABSPP and the CBPP3, the liquidity provided to the market by the combined monthly purchases amounted to $€ 60$ billion. ${ }^{19}$

PSPP Decision stated that: "This programme was taken as part of the single monetary policy in view of a number of factors that have materially increased the downside risk to the medium-term outlook on price developments, thus jeopardising the achievement of the European Central Bank's primary objective of maintaining price stability. These factors include lower than expected monetary stimulus

17 Recital 2 and Articles 1-2 of Decision (EU) 2015/5 of the European Central Bank of 19 November 2014 on the implementation of the asset-backed securities purchase programme (ECB/2014/45), OJ L 1, 6.1 .2015 , p. $4-7$

18 ECB Press release (2018): ECB decides on technical parameters for the reinvestment of its asset purchase programme, 13 December 2018, [https://www.ecb.europa.eu/press/pr/date/2018/html/ecb.pr181213. en.html] Accessed 03.04.2019

19 Decision (EU) 2015/774 of the European Central Bank of 4 March 2015 on a secondary markets public sector asset purchase programme (ECB/2015/10), OJ L 121 14.5.2015, p. 20 (PSPP Decision) 
from adopted monetary policy measures, a downward drift in most indicators of actual and expected euro area inflation — both headline measures and measures excluding the impact of volatile components, such as energy and food - towards historical lows, and the increased potential of second-round effects on wage and price-setting stemming from a significant decline in oil prices. The programme aim was to further ease monetary and financial conditions, including those relevant to the borrowing conditions of euro area non-financial corporations and households, thereby supporting aggregate consumption and investment spending in the euro area and ultimately contributing to a return of inflation rates to levels below but close to $2 \%$ over the medium term." ${ }^{20}$

On 28 April 2016 The European Central Bank initiated the second series of targeted longer-term refinancing operations that consisted of four targeted longerterm refinancing operations (TLTRO II), each with a maturity of four years. The aim was the same to further ease private sector credit conditions and stimulate credit creation. The TLTROs-II was also intended to strengthen the transmission of monetary policy by further incentivising bank lending to the non-financial private sector, i.e. households and non-financial corporations, in Member States whose currency is the euro. In conjunction with other non-standard measures in place, TLTROs-II aimed to contribute to a return of inflation rates to levels below, but close to $2 \%$ over the medium term. ${ }^{21}$

The seventh Asset purchases programme started on 1 June 2016 with the corporate bond purchase programme (CSPP). The European Central Bank issued Decision on the implementation of the corporate sector purchase programme (ECB/2016/16). Under the programme, the European Central Bank purchased corporate bonds in the primary and secondary markets. Marketable debt instruments issued by corporations was eligibility if they fulfil criteria for marketable assets for Eurosystem credit operations. ${ }^{22}$ This decision was taken in order to also: "Further strengthen the pass through of the European Central Bank asset purchases to the financing conditions of the real economy, and in order to provide, in conjunction with the other non-standard monetary policy measures in place, further monetary policy accommodation and contribute to a return of inflation rates to levels below, but close to, $2 \%$ over the medium term." ${ }^{23}$

\footnotetext{
20 Recital 3-4 of the PSPP Decision

21 Decision (EU) 2016/810 of the European Central Bank of 28 April 2016 on a second series of targeted longer-term refinancing operations (ECB/2016/10), OJ L 132, 21.5.2016, p. 107-128

22 Article 1-2 of the Decision (EU) 2016/948 of the European Central Bank of 1 June 2016 on the implementation of the corporate sector purchase programme (ECB/2016/16), OJ L 157, 15.6.2016, p. 28-32 (CSPP Decision)

23 Recital 3 of the CSPP Decision
} 
Under the Asset purchases programmes European Central Bank purchased cover bonds, asset backed securities, public and private sector securities.

Table 1: ECB holdings under the asset purchase programme

\begin{tabular}{|l|l|l|}
\hline & Monetary policy securities portfolios & Reported value as at 26 April 2019 \\
\hline 1 & Covered bond purchase programme 1 & $€ 3.2$ billion \\
\hline 2 & Securities Markets Programme & $€ 62.8$ billion \\
\hline 3 & Covered bond purchase programme 2 & $€ 3.5$ billion \\
\hline 4 & Covered bond purchase programme 3 & $€ 261.5$ billion \\
\hline 5 & Asset-backed securities purchase programme & $€ 26.2$ billion \\
\hline 6 & Public sector purchase programme & $€ 2,098.7$ billion \\
\hline 7 & Corporate sector purchase programme & $€ 177.6$ billion \\
\hline & $\begin{array}{l}\text { Total net result of the Asset purchases pro- } \\
\text { grammes }\end{array}$ & $€ 2,663.5$ billion \\
\hline
\end{tabular}

Source: European Central Bank, Open market operations

https://www.ecb.europa.eu/mopo/implement/omo/html/index.en.html

Table 1. shows that the net result of the Asset purchases programmes was $€ 2.66$ trillion at the end of April 2019 of public and private sector securities. Almost $80 \%$ of the purchased securities and more than $€ 2$ trillion have been issued by public sector entities.

Longer-term refinancing operations were part of the non-standard measures. The second series of targeted longer-term refinancing operations is still active and it consists of four targeted longer-term refinancing operations (TLTRO II) each with a maturity of four years.

Table 2: Outstanding amount and the maturity date of the second longer-term refinancing operations

\begin{tabular}{|l|l|l|l|l|}
\hline Type & Settlement date & Maturity date & Days & Outstanding amount \\
\hline TLTRO II & $29 / 03 / 2017$ & $24 / 03 / 2021$ & 1456 & $€ 230.47$ billion \\
\hline TLTRO II & $21 / 12 / 2016$ & $16 / 12 / 2020$ & 1456 & $€ 61.37$ billion \\
\hline TLTRO II & $28 / 09 / 2016$ & $30 / 09 / 2020$ & 1463 & $€ 44.18$ billion \\
\hline TLTRO II & $29 / 06 / 2016$ & $24 / 06 / 2020$ & 1456 & $€ 379.37$ billion \\
\hline Total: & & & & $€ 715.36$ billion \\
\hline
\end{tabular}

Source: European Central Bank, Open market operations

https://www.ecb.europa.eu/mopo/implement/omo/html/index.en.html

Table 2. shows that the second longer-term refinancing operations will mature in 2020 and 2021 and that the outstanding amount is $€ 715$ billion. 
By Asset purchases programmes and long term refinancing operations, European Central Bank extended its balance sheet assets for $€ 3.3$ trillion; from $€ 1.4$ trillion in $2007^{24}$ to $€ 4.7$ trillion in April 2019. ${ }^{25}$

\section{EFFECTS OF THE UNCONVENTIONAL MONETARY POLICY CONDUCTED BY THE EUROPEAN CENTRAL BANK}

The European Central Bank stated the aim of the asset purchase programmes and longer-term refinancing operations. The stated aim was to ease monetary and financial conditions, including those relevant to the borrowing conditions of the euro area non-financial corporations and households, to support aggregate consumption and investment spending in the euro area and ultimately contribute to a return of inflation rates to levels below but close to $2 \%$ over the medium term. The objectives were to promote decline in money market term rates, ease funding conditions for credit institutions and enterprises, encourage credit institutions to maintain and expand lending to corporations and households and to improve market liquidity in important segments of the private debt securities market.

Some of the stated aims and objectives were achieved. Non-standard measures improved liquidity of the banking system and the liquidity of the entire financial sector in the euro area. Improved liquidity brought more stability to the financial system and lowered the cost of operation of credit institutions. Credit institutions used the increased liquidity to pay down their more costly liabilities and replace the funding with less expensive liabilities to lower their expenditure. ${ }^{26}$ Large asset purchases programmes and longer-term refinancing operations have reduced long-term interest rates, preventing high liquidity premiums from depressing financial institutions and financial markets. ${ }^{27}$

The expectations were that credit institutions would use increased liquidity and lower short-term and long-term interest rates to grant loans to corporations and households to support investment and consumption, which would lead to economic growth and full employment. The expectations of economic growth and full employment have not been met as expected because granting loans and demands for the loans do not depends only on the liquidity and the interest rate. Central banks can supply financial sector with liquidity but cannot solve underly-

24 European Central Bank (2007): Consolidated financial statement of the Eurosystem as at 21 December 2007

25 European Central Bank (2019): Consolidated financial statement of the Eurosystem as at 26 April 2019

26 European Central Bank (2015): Economic Bulletin, Issue 7 / 2015 - Articles, p. 40-41

27 Guerini, M.; Lamperti, F.; Mazzocchetti, A., Unconventional Monetary Policy: Between the Past and Future of Monetary Economics, Working paper, S Growth, 2018, p. 5 
ing solvency problems or poor creditworthiness. Therefore, unconventional monetary policy measures can buy time and in the short run stabilise conditions but in the long run this is unsure. Likewise, low interest rates delay the acknowledgment of losses. Seven years after the financial crisis the recovery of the economies in the euro area remains weak. ${ }^{28}$

However, the macroeconomic effects seem to be quite different in the United States of America. While the effects in the euro area have been weak, the unconventional monetary policy have supported economic growth in the US economy. Some authors believe that it could be related to fiscal policy. According to Keynes, once nominal interest rates reach zero, monetary policy can do no more (zero lower bound). Thus, in the case of reaching the zero lower bound only fiscal policy could work since interest rates cannot go below zero. ${ }^{29}$ When the crisis started the debt-to-GDP ratio in USA was relatively low, and the unconventional monetary policy was combined with expansionary and strong fiscal policy, which increased the level of public debt but positively stimulated the US economy. In contrast to the USA, the euro area is a monetary union of 19 of the $28 \mathrm{EU}$ member states and each state is on a different level of economic development and with the different fiscal policy. Most of the EU economies entered the crisis endowed with already high debt-to-GDP ratios; this, combined with the compliance of the restrictive fiscal policy regime might help explain the different outcomes in the euro area and the USA. ${ }^{30}$ There is also no government debt instrument for the euro area as a whole, only national bonds. European Central Bank asset purchasing programmes therefore amounts to buying pro-rata shares of the debt of member states. Given that investors vastly prefer to hold German debt than Portuguese or Italian debt, European Central Bank policy involves actuarial transfers across governments, even if these transfers are not realized. ${ }^{31}$

Overall, unconventional monetary policy instruments such as asset purchasing programmes offer some theoretical promise for addressing the zero bound. However, these policies have now been conducted for some years, in the case of Japan for more than two decades, and at least so far, they have not convincingly shown an ability to decisively overcome the problems posed by the zero bound. ${ }^{32}$

Monetary policy has a restricted influence in stimulating economy and economic

\footnotetext{
28 Pereira, I., Is the ECB unconventional monetary policy effective?, GEE Papers, No. 61, 2016, p. 8-9

29 Ibid., p. 6

30 Guerini; Lamperti; Mazzocchetti, op. cit., note 27, p. 3-4

31 Rogoff, K., Dealing with Monetary Paralysis at the Zero Bound, Journal of Economic Perspectives, Vol. 31, No. 3, 2017, p. 53

32 Ibid., p. 54
} 
growth. The best contribution of monetary policy to economic growth is to ensure price stability. Environment of stable prices shall assist sustainable economic growth. Monetary policy can also provide money and liquidity at low interest rates, but monetary policy itself cannot induce economic growth because it cannot obligate corporations and households to borrow money and to invest or to consume. Without new investments and consumptions fresh liquidity will remain an unused potential with a weak effect to real economy. Only in cooperation with other policies, monetary policy can stimulate economic growth. Other policies that can stimulate economic growth are related to structural reforms, which can improve effectiveness in real economy. Fiscal policy with some tax relief can induce investments and consumption. Social policy that will support people in need can also stimulate consumption and increase demand for goods and services. These policies are difficult to implement, they are sometimes unpopular and take time. On the other hand, monetary policy is easier to conduct but without the support of these other policies, its results are weak.

\section{CONCLUSION}

The European Central Bank conducts monetary policy in the euro area. Standard monetary policy is conducted by managing the level of short-term interest rates. Managing the level of short-term interest rates the European Central Bank can influence the overall availability and cost of credits and can control the quantity of money in the euro area economy. If the level of the inflation rates are low and economic growth is weak European Central Bank can lower short-term interest rate to increase money supply in the economy. However, short-term interest rate policy has its limitations and the limit is zero lower bound, which means that the short-term interest rates cannot be set below $0 \%$.

European Central Bank and all major central banks have reduced short-term interest rates to zero or near zero to stimulate spending and investing with the expectations that this measure alone will be enough to induce economic growth. Contrary to expectations, lowering short-term interest rates has little effects on economies. Economic growth stagnated, inflation rates were very low with the tendency to deflation and the central banks had to use some other non-standard and unconventional measures to achieve price stability and to support economic growth.

The European Central Bank introduced Asset purchases programmes and Longerterm refinancing operations as non-standard monetary policy measures. European Central Bank conducted Asset purchases programmes from 2009 to 2018 and un- 
der the seven programmes purchased cover bonds, asset backed securities, public and private sector securities in the amount of more than $€ 2.6$ trillion. By Asset purchases programmes and long term refinancing operations, European Central Bank extended its balance sheet assets for $€ 3.3$ trillion, from $€ 1.4$ trillion in 2007 to $€ 4.7$ trillion in April 2019.

The objective of these non-standard monetary measures was to ease monetary and financial conditions, to expand lending to corporations and households and to support aggregate consumption and investment spending in the euro area.

The result of non-standard measures are improved liquidity of the banking system and the liquidity of the entire financial sector in the euro area. Improved liquidity brought more stability to the financial system. The long-term and the short-term credit interest rates are lower. However, the expectations of economic growth and full employment have not been met.

Monetary policy and all its standard and non-standard measures cannot alone achieve economic growth and full employment. Monetary policy can provide price stability, liquidity and credits at low interest rates but without cooperation of other policies the economic growth and full employment will not be achieved. Structural reforms can improve effectiveness in real economy. Fiscal policy with some tax relief can induce investments and consumption. Social policy that will support people in need can also stimulate consumption and increase demand for goods and services. These policies in cooperation with monetary policy can achieve results in sustainable economic growth and full employment.

\section{REFERENCES}

\section{BOOKS AND ARTICLES}

1. Abidi, N.; Miquel-Flores, I., Who benefits from the corporate QE? A regression discontinuity design approach, ECB Working Papers Series, No 2145, 2018

2. Andrade, P.; Breckenfelder, J.; De Fiore, F.; Karadi, P.; Tristani, O., The ECB's asset purchase programme: An early assessment, ECB Working Paper Series, No 1956, 2016

3. Avalos, F.; Mamatzakis, E.C., Euro area unconventional monetary policy and bank resilience, BIS Working Papers No 754, 2018

4. Castelnuovo, E.; Nicoletti-Altimari S.; Rodríguez-Palenzuela, D. Definition of price stability, range and point inflation targets: The anchoring of long-term inflation expectations, ECB Working Paper NO. 273, 2003

5. Coenen, G.; Ehrmann, M., Gaballo, G.; Hoffmann, P.; Nakov, A.; Nardelli, S.; Persson, E.; Strasser, G. Communication of monetary policy in unconventional times, ECB Working Paper Series, No 2080, 2017 
6. Cour-Thimann, P.; Winkler, B., The ECB's non-standard monetary policy measures - The role of institutional factors and financial structure, ECB Working Papers Series, No 1528, 2013

7. Cúrdia, V.; Woodford, M., Conventional and Unconventional Monetary Policy, FRB of New York Staff Report No. 404, 2009

8. Debarati, R., Power of money, Vij Books India Pvt. Ltd. New Delhi, 2011

9. Dell'Ariccia, G.; Rabanal, P.; Sandri, D., Unconventional Monetary Policies in the Euro Area, Japan, and the United Kingdom, Hutchins Center Working Paper \#48, 2018

10. Eser, F.; Schwaab, B., Evaluating the impact of unconventional monetary policy measures: Empirical evidence from the ECB's Securities Markets Programme, Journal of Financial Economics, Vol. 119, No. 1, January 2016, p. 147-167

11. Fratzscher, M.; Lo Duca, M.; Straub, R. (2014): ECB Unconventional Monetary Policy Actions: Market Impact, international Spillovers and Transmission Channels, 15th Jacques Polak Annual Research Conference, Washington, DC, November 13-14, 2014

12. Guerini, M.; Lamperti, F.; Mazzocchetti, A., Unconventional Monetary Policy: Between the Past and Future of Monetary Economics, Working paper, S Growth, April 25, 2018

13. Hermele, K., Commodity Currencies vs Fiat Money - Automaticity vs Embedment, University of Leeds, Fessud Working Paper Series, Vol. 44, 2014

14. König, S., The evolution of money: From Commodity Money to E-Money, UNICERT IV Program, July 6th, 2001

15. Laidler, D., Passive Money, Active Money, and Monetary Policy, Bank of Canada review, summer 1999

16. Pattipeilohy, C.; Willem van den End, J.; Tabbae, M.; Frost, J.; de Haan, J., Unconventional monetary policy of the ECB during the financial crisis: An assessment and new evidence, DNB Working Papers 381, Netherlands Central Bank, Research Department, 2013

17. Pereira, I., Is the ECB unconventional monetary policy effective?, GEE Papers No. 61, 2016

18. Rogoff, K., Dealing with Monetary Paralysis at the Zero Bound, Journal of Economic Perspectives, Vol. 31, No. 3, 2017, p. 47-66

19. Varghese, R.; Zhang, Y.S., A New Wave of ECB's Unconventional Monetary Policies: Domestic Impact and Spillovers, IMF Working Paper Strategy Policy and Review , 2018

20. Vivian, R.; Spearman, N., Banks and Money Creation 'Out of Nothing', Working Paper, December 2016

\section{EU LAW}

1. Decision (EU) $2015 / 5$ of the European Central Bank of 19 November 2014 on the implementation of the asset-backed securities purchase programme (ECB/2014/45), OJ L 1, 6.1.2015, p. 4-7

2. Decision (EU) $2015 / 774$ of the European Central Bank of 4 March 2015 on a secondary markets public sector asset purchase programme (ECB/2015/10), OJ L 121 14.5.2015, p. 20 
3. Decision (EU) 2016/810 of the European Central Bank of 28 April 2016 on a second series of targeted longer-term refinancing operations (ECB/2016/10), OJ L 132, 21.5.2016, p. 107-128

4. Decision (EU) 2016/948 of the European Central Bank of 1 June 2016 on the implementation of the corporate sector purchase programme (ECB/2016/16), OJ L 157, 15.6.2016, p. $28-32$

5. Decision of the European Central Bank of 14 May 2010 establishing a securities markets programme (ECB/2010/5) (OJ L 124, 20.5.2010), p. 8-9

6. Decision of the European Central Bank of 15 October 2014 on the implementation of the third covered bond purchase programme (ECB/2014/40), OJ L 335, 22.11.2014, p. 22-24

7. Decision of the European Central Bank of 2 July 2009 on the implementation of the covered bond purchase programme (ECB/2009/16), OJ L 175, 4.7.2009, p. 18-19

8. Decision of the European Central Bank of 29 July 2014 on measures relating to targeted longer-term refinancing operations (ECB/2014/34), OJ L 258, 29.8.2014, p. 11-29

9. Decision of the European Central Bank of 3 November 2011 on the implementation of the second covered bond purchase programme (ECB/2011/17) OJ L 297, 16.11.2011, p. 70-71

10. Guideline (EU) 2015/510 of the European Central Bank of 19 December 2014 on the implementation of the Eurosystem monetary policy framework (ECB/2014/60) OJ L 91, 2.4.2015, p. 3-135

11. Treaty on the Functioning of the European Union, OJ C 326, 26.10.2012, p. 1-12

\section{WEBSITE REFERENCES}

1. ECB Press release (2010): Covered bond purchase programme completed, ECB Frankfurt, 30 June 2010; [https://www.ecb.europa.eu/press/pr/date/2010/html/pr100630.en.html] Accessed 15.04.2019

2. ECB Press release (2011): ECB announces measures to support bank lending and money market activity, ECB Frankfurt, 8 December 2011; [https://www.ecb.europa.eu/press/pr/ date/2011/html/pr111208_1.en.html] Accessed 14.04.2019

3. ECB Press release (2018): ECB decides on technical parameters for the reinvestment of its asset purchase programme, 13 December 2018, [https://www.ecb.europa.eu/press/pr/ date/2018/html/ecb.pr181213.en.html] Accessed 02.04.2019

4. EuropeanCentralBank(2006):Pricestability-ObjectiveoftheEurosystem,ECB, MP.001,08/06, [https://www.ecb.europa.eu/ecb/educational/shared/img/MP_0806_300dpi-textsheet. en.pdf] Accessed 15.04.2019

5. European Central Bank (2007): Consolidated financial statement of the Eurosystem as at 21 December 2007; [https://www.ecb.europa.eu/press/pr/wfs/2007/html/fs071227.en.html] Accessed 12.03.2019

6. European Central Bank (2015): Economic Bulletin, Issue 7 / 2015; [https://www.ecb.europa.eu/pub/pdf/ecbu/eb201504.en.pdf?1ab1ac390dc60e25297ead66e7930567] Accessed 15.04.2019 
7. European Central Bank (2019): Consolidated financial statement of the Eurosystem as at 26 April 2019; [https://www.ecb.europa.eu/press/pr/wfs/2019/html/ecb.fst190430.en.html] Accessed 15.04.2019

8. European Central Bank, Open market operations; [https://www.ecb.europa.eu/mopo/implement/omo/html/index.en.html] Accessed 15.04.2019

9. Executive Board of the ECB (2011): The Monetary Policy of the ECB 2011, ECB, Frankfurt, [https://www.ecb.europa.eu/pub/pdf/other/monetarypolicy2011en.pdf] Accessed 12.04.2019 